\title{
A Review on Removal of Heavy Metal lons from Waste Water using Natural/ Modified Bentonite
}

\author{
Prathiksha P. Prabhu ${ }^{1 *}$, and Balakrishna Prabhu ${ }^{1}$ \\ ${ }^{1}$ Department of Chemical Engineering, Manipal Institute of Technology, Manipal, Manipal Academy \\ of Higher Education, India.
}

\begin{abstract}
The pollution of water due to various toxic components especially heavy metals are causing an adverse effect on the flora and fauna and also have a potential effect on the human well-being. Due to this there is an immediate requirement to find various techniques for the removal of lethal toxins in wastewater. Amongst all of the existing methods, adsorption is one of the most effective and efficient technique for the elimination of contaminants such as heavy metals from wastewater. The increasing number of research publications on adsorption of heavy metals using modified bentonite leads to the fact that there has been a surging importance in the production of a variety of economical adsorbents for water treatment. Outcome from the latest advances in using bentonites and modified bentonite shows the adaptable nature of the clay and its environment friendly nature. The present review shows the removal of heavy metals using modified bentonite. The main purpose of this review is to describe the flexible way of natural bentonite and modified bentonite and its ability to absorb array of inorganic pollutants, which are present in the waste water. It is apparent from the review that modified bentonite have displayed high removal potential for certain kind of inorganic contaminants from wastewater.
\end{abstract}

Keywords: Modified Bentonite, Adsorption, Heavy metals, Inorganic pollutants

\section{Introduction}

Industries have been evolving rapidly in the last few decades which have resulted in increase in all kinds of pollution one of which is water pollution. The accessibility of water supply with regard to both quality and quantity is important to human survival. The environmental concern due to globalization and rapid industrialization are becoming a hindrance for human being. Hence efficient and constructive methods are required specifically for process industries. Heavy metals accounted in wastewaters and industrial discharges are one of the major concerns of environmental pollution. Heavy metals are normally contemplated as those whose density exceeds $5 \mathrm{~g} / \mathrm{cm}^{3}$. Most of the components belonging to this grouping are extremely water soluble, popularly-known toxins and carcinogenic agents.

\footnotetext{
* Corresponding author: prathikshaprabhu25@gmail.com
} 
Heavy metals are contemplated to be the following elements: Lead, Copper, Zinc, Cadmium, Chromium, Nickel, Arsenic, Tin, Iron, Selenium, Molybdenum, Silver, Gold, Mercury, Cobalt, Aluminium and Manganese. These symbolize serious threats to the human populace and the animals and plants of the receiving water bodies. These can be soaked up and assembled in human body and cause consequential health issues like organ damage, cancer, nervous system damage, and in extreme cases, death. It's also observed to decrease growth and evolution. Heavy metals such as Lead, Copper, Zinc, Cadmium, Chromium, Nickel, Arsenic, Tin, Iron, Selenium, Molybdenum, Silver, Gold, Mercury, Cobalt, and Aluminum are produced in textile industry, leather tanning industry, zinc refineries, metallurgical industries, automobile emissions, incineration of metals, mining and refining of heavy metals, cement and asbestos industries, cadmium nickel batteries, fungicides, insecticides etc. Substantial amount of heavy metal wastes like lead, Tin, and nickel result from building construction waste, storage batteries, paints, cable coatings, and prosthetics containing $\mathrm{Ni}[1]$.

Chromated copper-arsenate wood processing industry generates selenium that contains wastes and inorganic pigment manufacturing industries generates pigments which contains cadmium sulfide and chromium compounds; petroleum refining produces conversion catalysts contaminated with vanadium, chromium and nickel; and photographic operations producing film with high concentrations of Ferro cyanide and silver. The adverse effect of heavy metal may manifest in various kinds of disorders like retardation of growth, decrease in longitivity, detrimental changes in reproductivity cycle, morbidity, formation of tumors, symptoms of chronic diseases, pathological changes, target organs affected by heavy metal pollutants are liver, brain, lungs, kidney, bones and teeth. These consequences are reduced by limiting the variety and concentration of heavy metals that may be present in the discharged wastewater. Hence it is a requirement to process and treat the metal polluted wastewater previous to its disposal to the surrounding environment. Heavy metal removal from inorganic effluent can be accomplished by frequently used treatment processes. Removal of heavy metals from industrial effluents can be achieved through various treatment techniques, including filtration or floatation, centrifugation, sedimentation, chemical precipitation, membrane processes such as reverse osmosis, Electrodialysis, ultrafiltration, ion exchange, coagulation/flocculation, adsorption [1].

\section{Conventional methods for removal of heavy metal}

\subsection{Chemical precipitation}

Chemical precipitation process refers to a process which includes the input of chemical components (reagents), continued with the segregation of the precipitated particles from the purified water. Removal of metals was brought about by the input of coagulants such as hydrated lime, alum, ferric chloride, chlorinated copperas and other organic polymers. Researchers found that $70 \%$ removal of $\mathrm{Cd}, \mathrm{Cu}$, and $\mathrm{Pb}$ from electroplating, textile and leather tanning industry wastewaters was possible by using coupled system of clariflocculator and hydroxide precipitation [2].

\subsection{Electro dialysis}

Electro Dialysis (ED) is an electro-chemical reduction of dissolved/colloidal species to elemental metal, transferred between two liquids through semi-permeable ion-exchange membranes under the influence of electric potential. The membranes either let positive or negatively charged ions i.e. either cations or anions to flow through them. An electro- 
motive force brings about the charge separation of metal ions according to the charge. Removal of $\mathrm{Cu}, \mathrm{Zn}$, and $\mathrm{Ni}$ takes place from this process $[2,3]$.

\subsection{Coagulation/ flocculation}

Coagulation is the most economical and effective means to remove impurities. The drinking or waste water are treated with certain chemicals in order to remove finely divided suspended solids and colloidal particles by forming "flocs". The chemicals used for coagulation are well mixed with baffled channels followed by mechanical stirring where the finely divided particles coalesce into larger particles and settle out. Pre-aeration for 5 mins before sedimentation helps in removal of entrained particles and improves flocculation. Various studies have been done to determine the effect of $\mathrm{pH}$, turbidity and quantity of coagulants on removals of impurities by this process $[2,3]$.

\subsection{Ultrafiltration}

Ultrafiltration is a type of membrane filtration in which the hydrostatic pressure forces a liquid against the membrane with pore sizes in the range of $0.1-0.001 \mu$. This process is used for the removal of suspended solids, colloids, organic and inorganic polymeric molecules. The advantage of ultrafiltration compared to conventional processes such as clarifiers and rotary filters are its high resistance to feed water quality. They are commercially available in hollow fiber, tubular plate and frame and spiral wound configurations. The typical feed pressure is $4-100$ psig $[2,3]$.

\subsection{Reverse osmosis}

This is a technique in which only the water molecules are allowed to pass through semipermeable membrane and does not let metal ions to pass through it. In this process the membrane is supported on a filter cloth and pressure is applied for the separation of concentrated side (side containing impurities) and dilute side (side containing pure water). This process finds application in various industrial applications such as removal of heavy metals or organics from industrial waste water from industries such as textile industry, pulp and paper industry, electroplating industry, fertilizer industry, leather tanning industry, rubber industry, detergent industry etc. [2, 3].

\subsection{Adsorption}

In this process, the gaseous and liquid effluents/solutes accumulate on porous solid adsorbents forming a thin film (adsorbate). The organic or inorganic solid/liquid or gaseous particles adhere onto the surface either by physical or chemical adsorption. The effectiveness of the process depends on various factors such as the surface area/unit weight of adsorbent, physical or chemical properties of the adsorbent and the nature of the particle being adhered on the surface of the adsorbent. This process is being used most often in comparison to the other techniques due to reasons such as cost effectiveness and easy mechanism. There are various adsorbents like silica gel, commercial zeolites, porous pellets of $\mathrm{NaF}$, iron oxide, pulverized lime stone or dolomite, alkalized alumina, bauxite, xanthate, chitosan, activated carbon, peat moss, bone gelatin beads, bentonite, lignin etc. The specific and selective nature of adsorbents renders the adsorbents effective only for few certain applications. The most commonly used adsorbent is activated carbon due to its highly porous structure, low cost and easy availability. It has the advantage of removing wide 
variety of small quantities of toxic metals. In certain cases industrial by-product or wastes are used as low cost adsorbents since they are locally available in enormous quantities due to which they are inexpensive. This process is widely used in water purification for removal of toxic metals, traces of organics and color [2, 3].

\section{Bentonite}

Bentonite is classed as natural clay of layered phyllosilicates, composed of alternating octahedral and tetrahedral sheets in the ratio of $2: 1$. The tetrahedral and octahedral sheets have a loose negative charge $\mathrm{Si}^{4+}$ and $\mathrm{Al}^{3+}$ in the crystal which is balanced out by reacting it with a lower valency cation such as sodium, calcium etc. The structure, chemical composition, exchangeable ion type and small crystal size contribute to the unique property of bentonite including a large chemically active surface area, high cation exchange capacity and high porosity. The porous structure is classified into macro pores, mesopores and microporores. The adsorption capacity depends on presence of micro and mesopores. Also, bentonite is easily available all over the world.

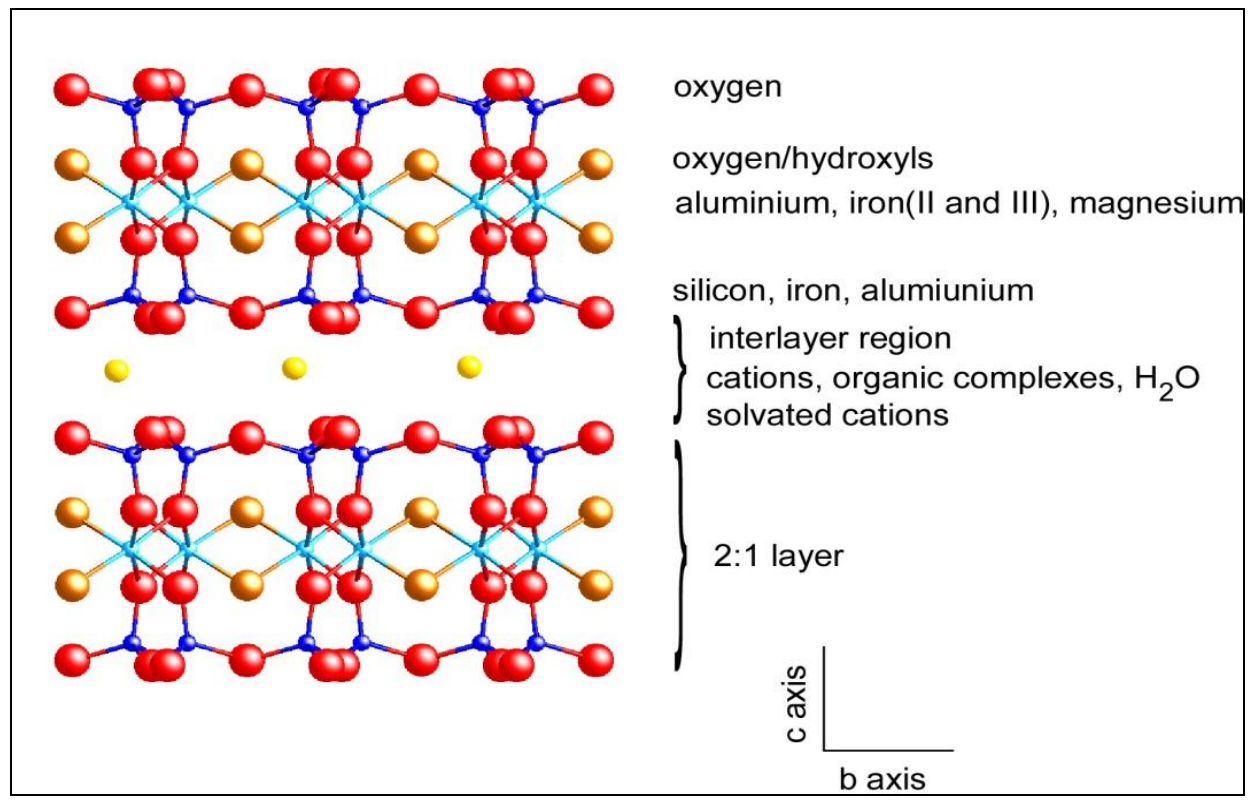

Fig. 1. Structure of Bentonite [1]

Bentonite finds various commercial application in syrups and wines, water purification, clarification and purification of sugar solutions, sewage and effluent treatment, pharmaceutical and therapeutic preparations, carrier for catalysts, refining and bleaching of glyceride oils carrier for fungicides, drilling fluids, fertilizer sprays, wall support for boreholes, formulation of ceramic glazes, non-drip paints, formulation of mortars, putties, adhesives, pelletizing animal feedstuffs, building agents for special moulding sands. Bentonite has advantages such as high surface area for adsorption, high porosity, and high cation exchange capacity and low cost while it also has the disadvantage that it requires modification for adsorption of anions. Modifying the structure of clay helped in increasing the surface area and sorption site thereby enhancing the adsorption capacity. Altering the 
structure of bentonite is required for improving its applicability for different processes. The composition of the bentonite clay varies depending on the type of operation it is being used for, adsorption capacity, from where it is obtained and the original layer charge.

Table 1. Surface and pore parameters of natural and modified bentonite.

\begin{tabular}{|c|c|c|c|c|}
\hline $\begin{array}{l}\text { S1. } \\
\text { no. }\end{array}$ & Adsorbent & Pore diameter & $\begin{array}{l}\text { Surface } \\
\operatorname{area}\left(\mathrm{m}^{2} / \mathrm{g}\right)\end{array}$ & Ref \\
\hline 1. & Natural Bentonite (B) & $9.8 \mathrm{~nm}$ & 27.6 & [4] \\
\hline 2. & Natrified Bentonite (Na-B) & $7.7 \mathrm{~nm}$ & 48.2 & [4] \\
\hline 3. & $\begin{array}{l}\text { Quartz sand bentonite } \\
\text { mixture(Mn-M) }\end{array}$ & $9.9 \mathrm{~nm}$ & 56.3 & [4] \\
\hline 4. & $\begin{array}{l}\text { Manganese Oxide onto } \\
\text { Sodium bentonite (Mn-NaB) }\end{array}$ & $12.9 \mathrm{~nm}$ & 25.9 & [4] \\
\hline 5. & $\begin{array}{l}\text { Sodium activated bentonite } \\
\text { (Na-AB) }\end{array}$ & & 150.3 & [5] \\
\hline 6. & $\begin{array}{l}\text { Bentonite supported nanoscale } \\
\text { zero valent Iron(B-nZVI) }\end{array}$ & $14.23 \mathrm{~nm}$ & 39.94 & [6] \\
\hline 7. & P4V4-Bentonite & $250 \mu \mathrm{m}$ & 27 & [7] \\
\hline 8. & GMZ-Bentonite & $53 \mu \mathrm{m}$ & 29.5 & [8] \\
\hline 9. & $\begin{array}{l}\text { Humic acid immobilized } \\
\text { amine modified } \\
\text { Polyacrylamide } \\
\text { bentonite(HA-Am-PAA-B) }\end{array}$ & & 336.3 & [9] \\
\hline 10. & $\begin{array}{l}\text { 8-Hydroxy quinine bentonite } \\
\text { (HQ-B) }\end{array}$ & $63 \mu \mathrm{m}$ & 45.69 & {$[10]$} \\
\hline 11. & $\begin{array}{l}\text { Polyacrylamide composite } \\
\text { bentonite (BENT-PAAm) }\end{array}$ & $53 \mu \mathrm{m}$ & 26.14 & [11] \\
\hline 12. & Activated Bentonite (ABn) & $4.6 \mathrm{~nm}$ & 29.1 & [12] \\
\hline 13. & $\begin{array}{l}\text { Manganese oxide coated } \\
\text { bentonite(MCB) }\end{array}$ & $7.82 \mu \mathrm{m}$ & 30 & [13] \\
\hline 14. & $\begin{array}{l}\text { Amine modified } \\
\text { Polyacrylamide } \\
\text { bentonite(Am-PAA-B) }\end{array}$ & & 203.5 & [9] \\
\hline
\end{tabular}

There are different methods by which the natural clays can be activated, few of which are acid activation, thermal activation, treatment with cationic surfactants, clay rubber composites, polymer addition, pillaring by different types of poly (hydrxo metal) cations, intraparticle and interparticle polymerization, dehydroxylation and calcination, delamination and reaggregation of smeclites, lyophillization, ultrasound and plasma, adsorption and ion exchange with inorganic and organic cations, binding of organic and inorganic anions and grafting of organic compounds [1]. The bentonite can be modified by addition of polymer in the interlayer of the clay spaces with the help of any simple process like physical adsorption or chemical grafting. The modification of bentonite with polymer improves the chemical and physical properties without actually altering its structure and nature of the clay. But has a disadvantage that the bond between the clay molecules and 
polymer is not very strong. The bentonite can also be modified by treating it with strong acids such as $\mathrm{HCl}$ and $\mathrm{H}_{2} \mathrm{SO}_{4}$ under favourable conditions of high temperature. The modification by acid activation helps alter the surface area, increases the sorption sites, enhances thermal stability and enhances adsorption capacity [1].

Table 2. Adsorption capacities of natural and modified bentonite

\begin{tabular}{|c|c|c|c|c|}
\hline $\begin{array}{l}\text { Sl. } \\
\text { no. }\end{array}$ & Adsorbent & $\begin{array}{l}\text { Metal ion } \\
\text { removed }\end{array}$ & $\begin{array}{l}\text { Adsorption } \\
\text { capacity }(\mathrm{mg} / \mathrm{g})\end{array}$ & Ref \\
\hline 1. & Natural Bentonite (B) & $\mathrm{Cd}(\mathrm{II})$ & 63.29 & [4] \\
\hline 2. & $\begin{array}{l}\text { Natrified Bentonite } \\
(\mathrm{Na}-\mathrm{B})\end{array}$ & $\mathrm{Cd}(\mathrm{II})$ & 72.99 & [4] \\
\hline 3. & $\begin{array}{l}\text { Quartz sand bentonite } \\
\text { mixture(Mn-M) }\end{array}$ & $\mathrm{Cd}(\mathrm{II})$ & 116.28 & {$[4]$} \\
\hline 4. & $\begin{array}{l}\text { Manganese Oxide onto } \\
\text { Sodium bentonite } \\
\text { (Mn-NaB) }\end{array}$ & $\mathrm{Cd}(\mathrm{II})$ & 108.69 & [4] \\
\hline 5. & Sodic Bentonite(B-Na) & $\mathrm{Cd}(\mathrm{II})$ & 29.4 & {$[14]$} \\
\hline 6. & $\begin{array}{l}\text { Bentonite Oxine } \\
\text { complex(B-Oxine) }\end{array}$ & $\mathrm{Cd}(\mathrm{II})$ & 61.4 & [14] \\
\hline 7. & $\begin{array}{l}\text { Sodium activated } \\
\text { bentonite } \\
\text { (Na-AB) }\end{array}$ & $\mathrm{Pb}(\mathrm{II})$ & 232.75 & [5] \\
\hline 8. & $\begin{array}{l}\text { Sodium activated } \\
\text { bentonite } \\
\text { (Na-AB) }\end{array}$ & $\mathrm{Cd}(\mathrm{II})$ & 28 & {$[5]$} \\
\hline 9. & $\begin{array}{l}\text { Sodium activated } \\
\text { bentonite } \\
\text { (Na-AB) }\end{array}$ & $\mathrm{Ni}(\mathrm{II})$ & 16 & {$[5]$} \\
\hline 10. & $\begin{array}{l}\text { Bentonite supported } \\
\text { nanoscale zero valent } \\
\text { Iron(B-nZVI) }\end{array}$ & $\mathrm{Cr}(\mathrm{VI})$ & 81.69 & [6] \\
\hline 11. & P4V4-Bentonite & $\mathrm{Cr}(\mathrm{VI})$ & 45.25 & [7] \\
\hline 12. & GMZ-Bentonite & $\mathrm{Cu}(\mathrm{IV})$ & 44.25 & [8] \\
\hline 13. & $\begin{array}{l}\text { Humic acid } \\
\text { immobilized amine } \\
\text { modified } \\
\text { Polyacrylamide } \\
\text { bentonite(HA-Am- } \\
\text { PAA-B) }\end{array}$ & $\mathrm{Cu}(\mathrm{II})$ & 112.5 & [9] \\
\hline 14. & $\begin{array}{l}\text { 8-Hydroxy quinine } \\
\text { bentonite } \\
\text { (HQ-B) }\end{array}$ & $\mathrm{Cu}(\mathrm{II})$ & 56.55 & {$[10]$} \\
\hline
\end{tabular}




\begin{tabular}{|c|l|l|l|l|}
\hline 15. & $\begin{array}{l}\text { Sodium activated } \\
\text { bentonite } \\
\text { (Na-AB) }\end{array}$ & $\mathrm{Cu}(\mathrm{II})$ & 30 & {$[5]$} \\
\hline 16. & $\begin{array}{l}\text { Polyacrylamide } \\
\text { composite bentonite } \\
\text { (BENT-PAAm) }\end{array}$ & $\mathrm{Cu}(\mathrm{II})$ & 33 & {$[11]$} \\
\hline 17. & $\begin{array}{l}\text { 4-methybenzo-15- } \\
\text { crown-5 } \\
\text { bentonite(MB15C5-B) }\end{array}$ & $\mathrm{Pb}(\mathrm{II})$ & 47.5 & {$[15]$} \\
\hline 18. & $\begin{array}{l}\text { 4-methybenzo-15- } \\
\text { crown-5 } \\
\text { bentonite(MB15C5-B) }\end{array}$ & $\mathrm{Cu}(\mathrm{II})$ & 34.2 & {$[15]$} \\
\hline 19. & $\begin{array}{l}\text { Manganese oxide } \\
\text { coated } \\
\text { bentonite(MCB) }\end{array}$ & $\mathrm{Cu}(\mathrm{II})$ & 58.88 & {$[13]$} \\
\hline 20. & $\begin{array}{l}\text { Acid activated } \\
\text { bentonite (AAB) }\end{array}$ & $\mathrm{Pb}(\mathrm{II})$ & 8.92 & {$[12]$} \\
\hline 21. & $\begin{array}{l}\text { 8-Hydroxy quinine } \\
\text { bentonite } \\
\text { (HQ-B) }\end{array}$ & $\mathrm{Pb}(\mathrm{II})$ & 142.94 & {$[16]$} \\
\hline 22. & $\begin{array}{l}\text { Manganese oxide } \\
\text { coated } \\
\text { bentonite(MCB) }\end{array}$ & $\mathrm{Pb}(\mathrm{II})$ & 55.88 & {$[13]$} \\
\hline
\end{tabular}

\section{Characterization of modified bentonite}

The surface properties of the bentonite on modification can be determined by various methods such as Brannuer-Emmet-Teller (BET) method, Fourier transform infra-red spectroscopy (FTIR), scanning electron microscopy (SEM) and X-Ray diffraction (XRD) method.

\subsection{Evaluation of pore size and surface area}

The specific surface areas of bentonite modified by acid activation, chemical grafting and physical adsorption are estimated using BET method. The pore width was determined from nitrogen adsorption and surface area analyzer. For homogenous and regular particles the specific surface area can be found using the following formulae:

$\mathrm{SSA}=($ Surface area/mass $)$

\subsection{Fourier transform infra-red spectroscopy}

FTIR spectroscopy is carried out in order to determine the change in structure and bonding between the clay molecules by the effect of acid activation, chemical grafting and physical adsorption. An IR spectrum is obtained post the modification by above mentioned processes. The sample should be powdered and dried completely prior to the analysis in order to prevent error while analysing the structure of the clay. 


\subsection{Scanning electron microscopy}

Bentonite samples are evaluated under scanning electron microscopy (SEM) to determine the morphological and elemental characteristics. The evaluation of the composition of the bentonite is done over a range of temperature using the sample of modified bentonite [17, $18]$.

\section{Modified bentonite for waste water treatment}

Bentonite is finding wide application due to its enhanced surface properties, low cost and improved sorption capacity. There are a number of clay minerals such as montmorillonite, TBA-montmorillonite, natural bentonite, poly (hydroxyl) zirconium-modified montmorillonite, clinoptilolite, Kaolinite, siderite, Ballclay, bentonite, coffee residue binding with clay, natural Jordanian clay and wollastonite that are widely used for the cost effective removal of chemical pollutants from wastewater. Among all of the above mentioned natural clays bentonite is finding wide application due to its easy availability and good adsorption characteristics [19].

\subsection{Modified Bentonite for removal of inorganic contaminants}

Heavy metals such as Lead Pb (II), Cadmium Cd (II), Chromium Cr (VI) and Copper $\mathrm{Cu}$ (II) $\& \mathrm{Cu}$ (IV) have a toxic effect on the living being and environment. Hence their removal is very vital for the survival of life.

\subsubsection{Cadmium Cd (II)}

The potential of removal of cadmium using diverse modification of bentonite was studied by various researchers. The adsorption capacity of quartz sand modified bentonite mixture (Mn-M)[1] was better than manganese oxide modified sodium bentonite (Mn-NaB), natrified bentonite(Na-B), bentonite oxine complex (B-Oxine) [12], sodic bentonite (B-Na) and sodium bentonite $(\mathrm{Na}-\mathrm{AB})[6]$. The effect of various parameters such as $\mathrm{pH}$, temperature, contact time, dose of adsorbent for the extraction of cadmium from aqueous solutions was studied. An optimum $\mathrm{pH}$ range of 5-6 was observed for cadmium removal using (Mn-M) \& (Mn-NaB) whereas a pH of 4 using (B-Na) and $\mathrm{pH}$ of 2-7 using (Na-AB). The optimum temperature range of $293-323 \mathrm{~K}$ was observed for using (B-Oxine) and a range of 290-328K using (Na-AB). The most suitable isotherm and kinetic model that best fits the experimental data was found. A 3-step mechanism was proposed for removal using (B-Na) which consisted of ion exchange step, complexation step and precipitation step [4, $5,14]$.

\subsubsection{Chromium $\mathrm{Cr}(\mathrm{VI})$}

The adsorption potential of various adsorbents such as bentonite supported nanoscale zero valent iron (B-nZVI) and (P4V4-bentonite) for removal of cadmium from aqueous solutions was studied by researchers $[5,6] .99 \% \mathrm{Cr}(\mathrm{VI})$ removal was achieved at $35^{\circ} \mathrm{C}$ using bentonite supported on nZVI whereas in comparison only $66 \% \mathrm{Cr}$ (VI) removal was observed using unsupported bentonite. For $\mathrm{Cr}$ (VI) removal at $25^{\circ} \mathrm{C}$ and $\mathrm{pH}$ of 1 using P4V4-bentonite showed clearly that the pyridinium's positive charge on polymer makes it efficient in chromium extraction. Amount of chromium adsorbed was calculated using

$$
\mathrm{Q}=\left(\mathrm{C}_{0}-\mathrm{C}_{\mathrm{t}}\right) \mathrm{m} / \mathrm{V}
$$


The researchers came to a conclusion that (B-nZVI) adsorbed better than (P4V4-bentonite). The adsorption of chromium was observed to increase with increase $\mathrm{pH}$, temperature, contact time with adsorbent and dosage of adsorbent $[6,7]$.

\subsubsection{Copper Cu (II) \&Cu (IV)}

The adsorption potential of various adsorbents such as GMZ Bentonite [8], Humic acid immobilized amine modified Polyacrylamide bentonite(HA-Am-PAA-B) [9], 8-Hydroxy quinoline immobilized bentonite (HQ-Bentonite) [10], Polyacrylamide complex of Bentonite (PAAm-Bentonite) [11], 4-methylbenzo-15-crown-5 Bentonite(MB15C5Bentonite) [15], Manganese oxide coated bentonite (MCB)[13] for removal of copper (II) $\& \mathrm{Cu}(\mathrm{IV})$ was studied. The optimum $\mathrm{pH}$ range for each of the above mentioned adsorbents was found to be $6.5,5-6,1.5-5.5,2.4-7,3.5-6$ and 3-6.5 respectively. The (Am-PAABentonite) on modification with humic acid was found to have higher thermal stability than just (Am-PAA-Bentonite). Desorption of $\mathrm{Cu}$ (II) and easy regeneration characteristic of (HA-Am-PAA-B) acts as a better adsorbent than others for copper removal. The thermodynamic parameters such as $\Delta \mathrm{G}^{\mathrm{o}}, \Delta \mathrm{H}^{\mathrm{o}}$ and $\Delta \mathrm{S}^{\mathrm{o}}$ were studied for each of the above adsorbents. The negative value of $\Delta \mathrm{G}^{\mathrm{o}}$ indicated that the adsorption was spontaneous under the applied conditions. The decrease in $\Delta \mathrm{G}^{0}$ with increasing temperature signified more efficient sorption at higher temperature. The positive value of $\Delta \mathrm{H}^{\circ}$ signified that the sorption was endothermic and that the increase in $\Delta \mathrm{H}^{\circ}$ increased the difficulty of sorption of $\mathrm{Cu}$ (II) ion on the adsorbent. The positive value of $\Delta \mathrm{S}^{0}$ showed affinity of metal ions on adsorbent and that $\mathrm{Cu}$ (II) ions are less hydrated in bentonite layers than in aqueous solutions. The positive value also indicated the randomness in the system with increase in hydration of adsorbing $\mathrm{Cu}$ (II) ions [8-13, 15, 23].

Table 3. Thermodynamic parameters for various adsorbents

\begin{tabular}{|c|c|c|c|c|c|c|}
\hline $\begin{array}{l}\text { Sl. } \\
\text { no. }\end{array}$ & Adsorbent & Temp. (k) & $\begin{array}{c}\delta \mathrm{g}^{\mathrm{o}} \\
\left(\mathrm{kjmol}^{-1}\right)\end{array}$ & $\begin{array}{c}\delta \mathrm{h}^{\mathrm{o}} \\
\left(\mathrm{kjmol}^{-1}\right)\end{array}$ & $\begin{array}{c}\delta \mathrm{s}^{\mathrm{o}} \\
\left(\mathrm{jmol}^{-1} \mathrm{k}^{-1}\right)\end{array}$ & Ref \\
\hline \multirow{2}{*}{1.} & \multirow{2}{*}{ GMZ Bentonite } & 293.15 & -16.26 & 1.24 & \multirow{2}{*}{59.7} & \multirow{2}{*}{ [8] } \\
\hline & & 313.15 & -17.76 & 0.935 & & \\
\hline \multirow{4}{*}{2.} & \multirow{4}{*}{ HA-Am-PAA-B } & 293 & 88.1 & \multirow{4}{*}{143.7} & \multirow{4}{*}{-251.7} & \multirow{4}{*}{ [9] } \\
\hline & & 303 & 90.6 & & & \\
\hline & & 313 & 93.2 & & & \\
\hline & & 323 & 95.6 & & & \\
\hline \multirow{4}{*}{3.} & \multirow{4}{*}{ HQ-Bentonite } & 293 & -24.14 & \multirow{4}{*}{17.18} & \multirow{4}{*}{140.69} & \multirow{4}{*}{ [10] } \\
\hline & & 303 & -25.45 & & & \\
\hline & & 313 & -26.12 & & & \\
\hline & & 323 & -28.46 & & & \\
\hline \multirow{3}{*}{4.} & \multirow{3}{*}{ PAAm-Bentonite } & 293.15 & -22.68 & 28.46 & \multirow{3}{*}{174.9} & \multirow{3}{*}{ [11] } \\
\hline & & 313.15 & -27.56 & 27.78 & & \\
\hline & & 323.15 & -30.18 & 28.53 & & \\
\hline \multirow{2}{*}{5.} & \multirow{2}{*}{ Bentonite } & 293.15 & -20.37 & \multirow{2}{*}{20.62} & \multirow{2}{*}{139.82} & \multirow{2}{*}{ [12] } \\
\hline & & 318.15 & -23.86 & & & \\
\hline \multirow{2}{*}{6.} & \multirow{2}{*}{$\mathrm{MCB}$} & 303 & -9.50 & \multirow{2}{*}{$\begin{array}{c}43.81 \pm \\
5.22\end{array}$} & \multirow{2}{*}{$\begin{array}{c}175.85 \pm \\
238\end{array}$} & \multirow[t]{2}{*}{ [13] } \\
\hline & & 313 & -11.25 & & & \\
\hline
\end{tabular}


Table 4. Parameters comparison between various modified bentonite

\begin{tabular}{|c|c|c|c|c|c|c|c|c|c|c|}
\hline $\begin{array}{r}\text { Sl } \\
\text { no. }\end{array}$ & $\begin{array}{c}\text { Adsorbent } \\
\text { used }\end{array}$ & $\begin{array}{l}\text { Metal } \\
\text { ion } \\
\text { removed }\end{array}$ & $\mathrm{Ph}$ & $\begin{array}{l}\text { Conta } \\
\text { ct } \\
\text { time }\end{array}$ & Rpm & $\begin{array}{l}\text { Dose of } \\
\text { adsorbent } \\
(\mathrm{mg} / \mathrm{l})\end{array}$ & $\begin{array}{l}\text { Temp } \\
\text { (k) }\end{array}$ & $\begin{array}{l}\text { Characte } \\
\text { rization }\end{array}$ & Isotherm & Ref \\
\hline 1 & $\begin{array}{c}\mathrm{Na}- \\
\text { bentonite }\end{array}$ & $\begin{array}{l}\mathrm{Pb}(\mathrm{II}), \\
\mathrm{Cd}(\mathrm{II}) \\
\mathrm{Ni}(\mathrm{II})\end{array}$ & $2-7$ & $\begin{array}{c}1,3,5, \\
10,15, \\
20,30, \\
40,50, \\
60 \mathrm{~min} \\
\mathrm{~s}\end{array}$ & $\begin{array}{c}50, \\
100, \\
150, \\
200\end{array}$ & $\begin{array}{c}0.125, \\
0.250 \\
0.375 \\
0.5\end{array}$ & $\begin{array}{l}290, \\
298, \\
313, \\
328\end{array}$ & $\begin{array}{c}\text { FT- } \\
\text { IR,XRF, } \\
\text { XRD }\end{array}$ & $\begin{array}{l}\text { Freundlich, } \\
\text { Langmuir }\end{array}$ & [5] \\
\hline 2 & $\begin{array}{c}\text { Na- } \\
\text { bentonite }\end{array}$ & $\mathrm{Pb}(\mathrm{II})$ & $3-7$ & $\begin{array}{l}180- \\
1440 \\
\text { mins }\end{array}$ & $\begin{array}{l}5000- \\
9000\end{array}$ & - & $\begin{array}{l}298 \\
318 \\
338\end{array}$ & $\begin{array}{c}\text { FT-IR, } \\
\text { XRD }\end{array}$ & $\begin{array}{c}\text { D-R } \\
\text { isotherm, } \\
\text { Freundlich, } \\
\text { Langmuir }\end{array}$ & [21] \\
\hline 3 & $\begin{array}{c}\text { Mn } \\
\text { immobilize } \\
\text { d bentonite } \\
\text { \& bentonite } \\
\text { Quartz }\end{array}$ & Cd(II) & $5-6$ & $\begin{array}{c}30- \\
1500 \\
\text { mins }\end{array}$ & 700 & $10-700$ & $\begin{array}{l}298 \\
(+ \text { or } \\
-) 10\end{array}$ & $\begin{array}{c}\text { XRD, } \\
\text { SEM } \\
\text { analysis }\end{array}$ & Langmuir & [4] \\
\hline 4 & $\begin{array}{l}\text { Hydroxy } 8 \text { - } \\
\text { quinolene } \\
\text { Intercalated } \\
\text { bentonite }\end{array}$ & Cd(II) & $\begin{array}{c}5.6- \\
11\end{array}$ & $\begin{array}{c}15- \\
180 \\
\operatorname{mins}\end{array}$ & 3000 & $4-100$ & $\begin{array}{l}293- \\
323\end{array}$ & $\begin{array}{c}\text { XRD, } \\
\text { SEM } \\
\text { analysis }\end{array}$ & Langmuir & [5] \\
\hline 5 & $\begin{array}{c}\text { Poly(4 } \\
\text { vinyl } \\
\text { Pridinium) } \\
\text { bentonite }\end{array}$ & $\mathrm{Cr}(\mathrm{IV})$ & $\begin{array}{l}1- \\
11\end{array}$ & $\begin{array}{c}0- \\
1440 \\
\text { mins }\end{array}$ & $\begin{array}{c}\text { Ten } \\
\text { thou- } \\
\text { sand }\end{array}$ & $25-200$ & $\begin{array}{c}2298- \\
333\end{array}$ & $\begin{array}{c}\text { FT-IR, } \\
\text { XRD }\end{array}$ & $\begin{array}{l}\text { Freundlich, } \\
\text { Langmuir }\end{array}$ & [22] \\
\hline 6 & $\begin{array}{l}\text { Natural } \\
\text { Bentonite }\end{array}$ & $\begin{array}{l}\mathrm{Cu}(\mathrm{II}), \\
\mathrm{Cd}(\mathrm{II})\end{array}$ & - & $\begin{array}{l}5-60 \\
\operatorname{mins}\end{array}$ & 1500 & $50-300$ & $\begin{array}{l}298, \\
308, \\
318, \\
328, \\
348\end{array}$ & $\begin{array}{c}\text { FT-IR, } \\
\text { SEM } \\
\text { analysis }\end{array}$ & $\begin{array}{l}\text { Freundlich, } \\
\text { Langmuir }\end{array}$ & [22] \\
\hline 7 & $\begin{array}{c}\text { Nanoscale } \\
\text { Zero valent } \\
\text { Iron } \\
\text { (n-ZVI) } \\
\text { Bentonite }\end{array}$ & $\mathrm{Cr}(\mathrm{VI})$ & $\begin{array}{l}3,7, \\
9,11\end{array}$ & $\begin{array}{c}0- \\
30 \mathrm{~min} \\
\mathrm{~s}\end{array}$ & 150 & $\begin{array}{c}0.25 \\
0.5 \\
0.75 \\
1.0 \\
1.5\end{array}$ & $\begin{array}{l}298 \\
(+ \text { or } \\
-) 10\end{array}$ & $\begin{array}{c}\text { XRD, } \\
\text { SEM } \\
\text { analysis, } \\
\text { XRF }\end{array}$ & $\begin{array}{c}\text { D-R } \\
\text { isotherm, } \\
\text { Langmuir }\end{array}$ & [6] \\
\hline 8 & $\begin{array}{c}\text { GMZ } \\
\text { Bentonite }\end{array}$ & $\mathrm{Cu}(\mathrm{II})$ & $\begin{array}{l}5- \\
6.5\end{array}$ & $\begin{array}{c}0- \\
1440 \\
\text { mins }\end{array}$ & 9000 & $1-3$ & $\begin{array}{l}293 \\
313 \\
333\end{array}$ & $\begin{array}{l}\text { XRD, } \\
\text { FT-IR }\end{array}$ & $\begin{array}{c}\text { D-R } \\
\text { isotherm, } \\
\text { Langmuir }\end{array}$ & [8] \\
\hline 9 & $\begin{array}{c}\text { Humic-acid } \\
\text { Immobilize } \\
\text { d } \\
\text { Bentonite }\end{array}$ & $\mathrm{Cu}(\mathrm{II})$ & $4-7$ & $\begin{array}{c}0- \\
300 \mathrm{mi} \\
\mathrm{ns}\end{array}$ & 200 & $25-100$ & $283-333$ & FT-IR & $\begin{array}{c}\text { D-R } \\
\text { isotherm, } \\
\text { Freundlich, } \\
\text { Langmuir }\end{array}$ & [9] \\
\hline
\end{tabular}




\begin{tabular}{|c|c|c|c|c|c|c|c|c|c|c|}
\hline 10 & $\begin{array}{c}\text { 8-hydroxy } \\
\text { Quinoline } \\
\text { Immobiliz- } \\
\text { ed } \\
\text { Bentonite }\end{array}$ & $\mathrm{Cu}(\mathrm{II})$ & $\begin{array}{l}1.5- \\
5.5\end{array}$ & $\begin{array}{c}10- \\
180 \\
\text { mins }\end{array}$ & - & $1-2$ & $\begin{array}{l}293 \\
303, \\
313, \\
323\end{array}$ & $\begin{array}{c}\text { XRD, } \\
\text { SEM } \\
\text { analysis, } \\
\text { XRS, } \\
\text { FT-IR }\end{array}$ & $\begin{array}{c}\text { D-R } \\
\text { isotherm, } \\
\text { Freundlich, } \\
\text { Langmuir }\end{array}$ & [10] \\
\hline 11 & $\begin{array}{l}\text { Activated } \\
\text { bentonite }\end{array}$ & $\begin{array}{l}\mathrm{Cu}(\mathrm{II}), \\
\mathrm{Pb}(\mathrm{II})\end{array}$ & $2-9$ & $\begin{array}{c}0- \\
720 \mathrm{mi} \\
\mathrm{ns}\end{array}$ & 400 & $1-20$ & $275-343$ & $\begin{array}{l}\text { XRD- } \\
\text { IRS, } \\
\text { FT-IR, } \\
\text { SEM } \\
\text { analysis }\end{array}$ & Langmuir & [12] \\
\hline 12 & $\begin{array}{l}\text { Sintered } \\
\text { bentonite }\end{array}$ & $\begin{array}{l}\mathrm{Pb}(\mathrm{II}), \\
\mathrm{Zn}(\mathrm{II})\end{array}$ & $3-5$ & $\begin{array}{c}0- \\
1800 \\
\text { mins }\end{array}$ & $\begin{array}{c}120 \\
(+ \text { or }- \\
\quad 10\end{array}$ & $0-200$ & $\begin{array}{l}298 \\
(+ \text { or } \\
-) 10\end{array}$ & $\begin{array}{c}\text { XRF, } \\
\text { XRD, } \\
\text { SEM } \\
\text { analysis }\end{array}$ & Langmuir & [21] \\
\hline
\end{tabular}

\subsubsection{Lead Pb (II)}

The adsorption capacity of various adsorbents such as manganese oxide coated bentonite (MCB) [20], acid activated bentonite (ABn) [12], 8-Hydroxy quinoline immobilized bentonite (HQ-Bentonite) [16] and sodium activated bentonite (Na-AB) for removal of lead was studied. Adsorption of lead on MCB is influenced by $\mathrm{pH}$ which was found to be optimum around 6; ionic strength increased from 0.01 to 0.1 and temperature was found to be optimum in the range 303 to $338 \mathrm{~K}$. Bentonite was activated using $6 \mathrm{~N} \mathrm{H}_{2} \mathrm{SO}_{4}$ to give $\mathrm{AAB}$, it was found that specific surface area and pore volume increased by 3.3 times the raw bentonite $(\mathrm{RB})$. The most suitable isotherm and kinetic model for removal of metal ion was determined. A comparative study of the adsorption capacity for various adsorbents was done and is shown in the table below.

Table 5. Adsorption capacity of various clay-based adsorbents for removal of lead (II) ions [16]

\begin{tabular}{|l|l|l|}
\hline SL. NO. & Adsorbent & Adsorption capacity $\left(\mathrm{mgg}^{-1}\right)$ \\
\hline 1. & Montmorillonite & 31.05 \\
\hline 2. & Poly(hydroxyl) zirconium-modified montmorillonite & 31.44 \\
\hline 3. & TBA-montmorillonite & 30.67 \\
\hline 4. & Natural bentonite & 20.00 \\
\hline 5. & Clinoptilolite & 62.00 \\
\hline 6. & Kaolinite & 19.27 \\
\hline 7. & Siderite & 14.06 \\
\hline 8. & Ballclay & 3.52 \\
\hline 9. & Coffee residue binding with clay & 19.50 \\
\hline 10. & Natural Jordanian clay & 66.24 \\
\hline 11. & Wollastonite & 1.68 \\
\hline 12. & 8-Hydroxy quinoline-immobilized bentonite & 142.94 \\
\hline 13. & Illite & 4.29 \\
\hline 14. & Acid activated bentonite & 13.05 \\
\hline
\end{tabular}

\section{Conclusions}

Removal of heavy metals has been extensively studied using various adsorbents and still research is being continued on which technique among the various available conventional 
methods is most efficient. In this review paper adsorption was used as technique for removal using different types of modified bentonite and their capacities to effectively remove heavy metals from waste water was compared and following are some findings:

1. Most of the modified bentonite has good potential for adsorption of heavy metals.

2. Initially for higher metal ion concentration in waste water, the uptake of metal ion by the adsorbent was high and then slowly reached equilibrium.

3. Adsorption isotherms of two parameter and three parameter was used for studies and it was observed that sorption by various adsorbents has been found to fit well by Freundlich and/or Langmuir isotherm models.

4. Adsorption kinetics for the adsorption processes was found to fit well with the pseudo-second-order kinetic model rather than pseudo-first-order kinetic model and intra-particle diffusion.

5. The effect was various parameters such as the $\mathrm{pH}$, temperature, dose of the adsorbent, contact time; agitation speed and adsorption capacity etc. was compared for different modified bentonite.

\section{References}

1. Manjot Kaur Toor, "Enhancing adsorption capacity of bentonite for dye removal: physicochemical modification and characterization", Clays Clay Miner 77-120 (2010)

2. Robert W. Peters and Linda Shem, "Separation of heavy metals: removal from industrial wastewaters and contaminated soil", Desalination 244 91-96 (2011)

3. Debasree Purkayasthha, Umesh Mishra, Swarup Biswas, "A comprehensive review on Cd (II) removal from aqueous solution”, J. Water Process Eng. 2 105-128 (2014)

4. Dimple Lakherwal, “Adsorption of heavy metals: A review”, Int. J. Environ. Res. Dev. 1 41-48 (2014)

5. TomášSchütz, Silvia Dolinská, PavolHudec, Annamária Mockovčiaková, Ingrid Znamenáčkova, "Cadmium adsorption on manganese modified bentonite and bentonite-quartz sand blend", Int. J. Miner. Process. 150 32-38 (2016)

6. A.A. Taha, Mohamed A. Shreadah, A.M. Ahmed, Hany Fathy Heiba, "Multicomponent adsorption of $\mathrm{Pb}$ (II), Cd (II), and $\mathrm{Ni}$ (II) onto Egyptian Na-activated bentonite; equilibrium, kinetics, thermodynamics, and application for seawater desalination", J. Environ. Chem. Eng. 4 1166-1180 (2016)

7. Li-na Shi, Yu-Man Lin, Xin Zhang, Zu-liang Chen, "Synthesis, characterization and kinetics of bentonite supported nZVI for the removal of $\mathrm{Cr}(\mathrm{VI})$ from aqueous solution”, Chem. Eng. J. 171 612-617 (2011)

8. A. Mansria, K.I. Benabadji, J. Desbrières, J. François, "Chromium removal using modified poly(4-vinylpyridinium) bentonite salts”, Desalination 245 95-107 (2009)

9. Jiaxing Li, Jun Hu, Guodong Sheng, Guixia Zhao, Qing Huang, "Effect of pH, ionic strength, foreign ions and temperature on the adsorption of $\mathrm{Cu}$ (II) from aqueous solution to GMZ bentonite", Colloids Surf., A 349 195-201 (2009)

10. T.S. Anirudhan, P.S. Suchithra, "Humic acid-immobilized polymer/bentonite composite as an adsorbent for the removal of copper (II) ions from aqueous solutions and electroplating Industry wastewater", J. Ind. Eng. Chem. 16 130-139 (2010)

11. Ozer G, Adnan Ozcan, Bilge Erdem, A. SafaOzcan, "Prediction of the kinetics, equilibrium and thermodynamic parameters of adsorption of copper (II) ions onto 8hydroxy quinoline Immobilized bentonite”, Colloids Surf., A 317 174-185 (2008) 
12. GuixiaZhaoa, HongxiaZhang, QiaohuiFan, XuemeiRen, Jiaxing Li, Yixue Chena, Xiangke Wang, "Sorption of copper (II) onto super-adsorbent of bentonitePolyacrylamide Composites”, J. Hazard. Mater. 173 661-668 (2010)

13. Radheshyam R. Pawar, Lalhmunsiama, Hari C. Bajaj, Seung-Mok Lee, "Activated bentonite as a low-cost adsorbent for the removal of $\mathrm{Cu}$ (II) and $\mathrm{Pb}$ (II) from aqueous solutions: Batch and column studies", J. Ind. Eng. Chem. 34 213-223 (2016)

14. E. Eren, A. Tabak, B. Eren, "Performance of magnesium oxide-coated bentonite in removal process of copper ions from aqueous solution", Desalination 257 163-169 (2010)

15. A. Bentouami, M.S. Ouali, "Cadmium removal from aqueous solutions by hydroxy- 8 quinoleine intercalated bentonite”, J. Colloid Interface Sci. 293 270-277 (2006)

16. Liu Yun, Shen Xing, Xian Qiming, Chen Haidong, Zou Huixian, Gao Shixiang, "Adsorption of copper and lead in aqueous solution onto bentonite modified by 4 methylbenzo-15-crown-5", J. Hazard. Mater. B137 1149-1155 (2006)

17. Stella Triantafyllou, E. Irini Christodoulou, and Paraskevi Neou-Syngouna, "Removal Of Nickel And Cobalt From Aqueous Solutions By Na-Activated Bentonite", Clays Clay Miner. 5 567-572 (1999)

18. A. Mellah and S. Chegrouche, "The Removal of Zinc from Aqueous Solutions by Natural Bentonite", War. Res. 3 621-629 (1997)

19. C. Femina Carolina, P. Senthil Kumara, A. Saravanan, G. Janet Joshiba, Mu. Naushad, "Efficient techniques for the removal of toxic heavy metals from aquatic environment: A review”, J. Environ. Chem. Eng. 5 2782-2799 (2017)

20. A. Safa Ozcan, Ozer G, Adnan Ozcan, “Adsorption of lead (II) ions onto 8-hydroxy quinoline-immobilized bentonite", J. Hazard. Mater. 161 499-509 (2009)

21. E. Eren, B. Afsin, Y. Ona, "Removal of lead ions by acid activated and manganese oxide coated bentonite J. Hazard. Mater. 161 677-685 (2009)

22. Shitong Yanga, DonglinZhao, Hui Zhang, Songs hengLud, Lei Chen, Xianjin Yu, "Impact of environmental conditions on the sorption behavior of $\mathrm{Pb}$ (II) in $\mathrm{Na}$ bentonite suspensions", J. Hazard. Mater. 183 632-640 (2010)

23. N. Karapinar, R. Donat, "Adsorption behaviour of $\mathrm{Cu} 2+$ and $\mathrm{Cd} 2+$ onto natural bentonite", Desalination 249 123-129 (2009) 